\title{
Millennial variability of rates of sea-level rise in the ancient harbour of Naples (Italy, western Mediterranean Sea)
}

\author{
Matteo Vacchi ${ }^{\text {* }}$ (1), Elda Russo Ermolli ${ }^{\mathrm{b}}$, Christophe Morhange ${ }^{\mathrm{c}, \mathrm{d}}$, Maria R. Ruello $^{\mathrm{b}}$, Valentino Di Donato ${ }^{\mathrm{b}}$, Mauro A. Di Vito ${ }^{\mathrm{e}}$, \\ Daniela Giampaola ${ }^{\mathrm{f}}$, Vittoria Carsana ${ }^{\mathrm{f}}$, Viviana Liuzza ${ }^{\mathrm{b}}$, Aldo Cinque ${ }^{\mathrm{b}}$, Giulia Boettog, Pierre Poveda ${ }^{\mathrm{g}}$, Giuliana Boenzif \\ Nick Marriner ${ }^{\mathrm{h}}$ \\ ${ }^{a}$ Dipartimento di Scienze Della Terra, Università di Pisa, 56126 Pisa, Italy \\ 'Dipartimento di Scienze della Terra, dell'Ambiente e delle Risorse, Università di Napoli Federico II, 80126 Naples, Italy \\ ${ }^{\mathrm{c}}$ Aix Marseille Université, CNRS, IRD, Coll France, CEREGE, 13545 Aix-en-Provence, France \\ ${ }^{\mathrm{d}}$ The Leon Recanati Institute for Maritime Studies at the University of Haifa (RIMS), Haifa 31905, Israel \\ ${ }^{\mathrm{e}}$ Istituto Nazionale di Geofisica e Vulcanologia, sezione di Napoli Osservatorio Vesuviano, 80124 Naples, Italy \\ ${ }^{\mathrm{f}}$ Soprintendenza Archeologia, Belle arti e Paesaggio per il comune di Napoli, 80132 Naples, Italy \\ ${ }^{\mathrm{g}}$ Aix Marseille Université, CNRS, CCJ, 13094 Aix-en-Provence, France \\ ${ }^{\text {h}}$ CNRS, ThéMA UMR 6049, Université de Bourgogne Franche-Comté, 32 rue Mégevand, Besançon Cedex, 25030, France \\ *Corresponding author: e-mail address: matteo.vacchi@unipi.it (M. Vacchi).
}

(Received February 26, 2019; ACCEPTED August 19, 2019)

\begin{abstract}
We reconstructed the late Holocene relative sea-level (RSL) evolution of the ancient harbour of Naples, one of the largest coastal conurbations in the Mediterranean. We carried out multiproxy investigations, coupling archaeological evidence with biological indicators. Our data robustly constrain $2000 \mathrm{yr}$ of non-monotonic changes in sea level, chiefly controlled by the complex volcano-tectonic processes that characterize the area. Between $\sim 200 \mathrm{BC}$ and $\mathrm{AD} \sim 0$, a subsidence rate of more than $\sim 1.5 \mathrm{~mm} / \mathrm{yr}$ enhanced the postglacial RSL rise, while negligible or moderate land uplift $<\sim 0.5 \mathrm{~mm} / \mathrm{yr}$ triggered a RSL stabilization during the Roman period (first five centuries AD). This stabilization was followed by a post-Roman enhancement of the sea-level rise when ground motion was negative, attested by a subsidence rate of $\sim 0.5$ to $\sim 1 \mathrm{~mm} / \mathrm{yr}$. Our analysis seems to indicate very minor impacts of this nonmonotonic RSL evolution on the activities of the ancient harbour of Naples, which peaked from the third century BC to the second century AD. After this period, the progressive silting of the harbour basin made it impossible to safely navigate within the basin, leading to the progressive decline of the harbour.
\end{abstract}

Keywords: Geo-archeology; Sea-level changes; Ancient harbours; Naples; Volcano-tectonics; Mediterranean Sea; Parthenope-Neapolis

\section{INTRODUCTION}

Past records of coastal evolution represent a key tool to interpret the future modifications of littoral areas in the context of global change (e.g., Pirazzoli, 1997; Kemp et al., 2011). Within this scope, several recent studies have sought to reconstruct late Holocene (i.e., last 4000 yr) coastal changes along the global coastlines using a wide range of proxies (e.g., Barlow et al., 2013; Khan et al., 2015; Seeliger et al., 2017). In this article, we present the results of a geoarchaeological survey revealing $\sim 4000$ yr of relative sea-level (RSL) evolution in the ancient harbour of the Graeco-Roman town

Cite this article: Vacchi, M. et al 2019. Millennial variability of rates of sea-level rise in the ancient harbour of Naples (Italy, western Mediterranean Sea). Quaternary Research 1-15. https://doi.org/10.1017/qua.2019.60 of Parthenope-Neapolis (Naples, western Mediterranean; Fig. 1A).

This part of the Italian coast lies in a very complex geodynamic setting, and its Holocene geomorphological evolution has primarily been controlled by both tectonics and active volcanism (Fig. 1B, e.g., Milia et al., 2006; Ferranti et al., 2010; Aucelli et al., 2017b). The aim of this article is to better constrain the role of these factors in the area of Naples, one of the largest coastal conurbations in the Mediterranean. In particular, we aimed to better quantify the timing and magnitude of land-level changes that significantly influenced the rates of RSL variation in the last four millennia.

Many Mediterranean coastal cities have a long history, in some cases extending back thousands of years (e.g., Bini et al., 2018). For this reason, the development of methodological approaches adapted to interpretation of 


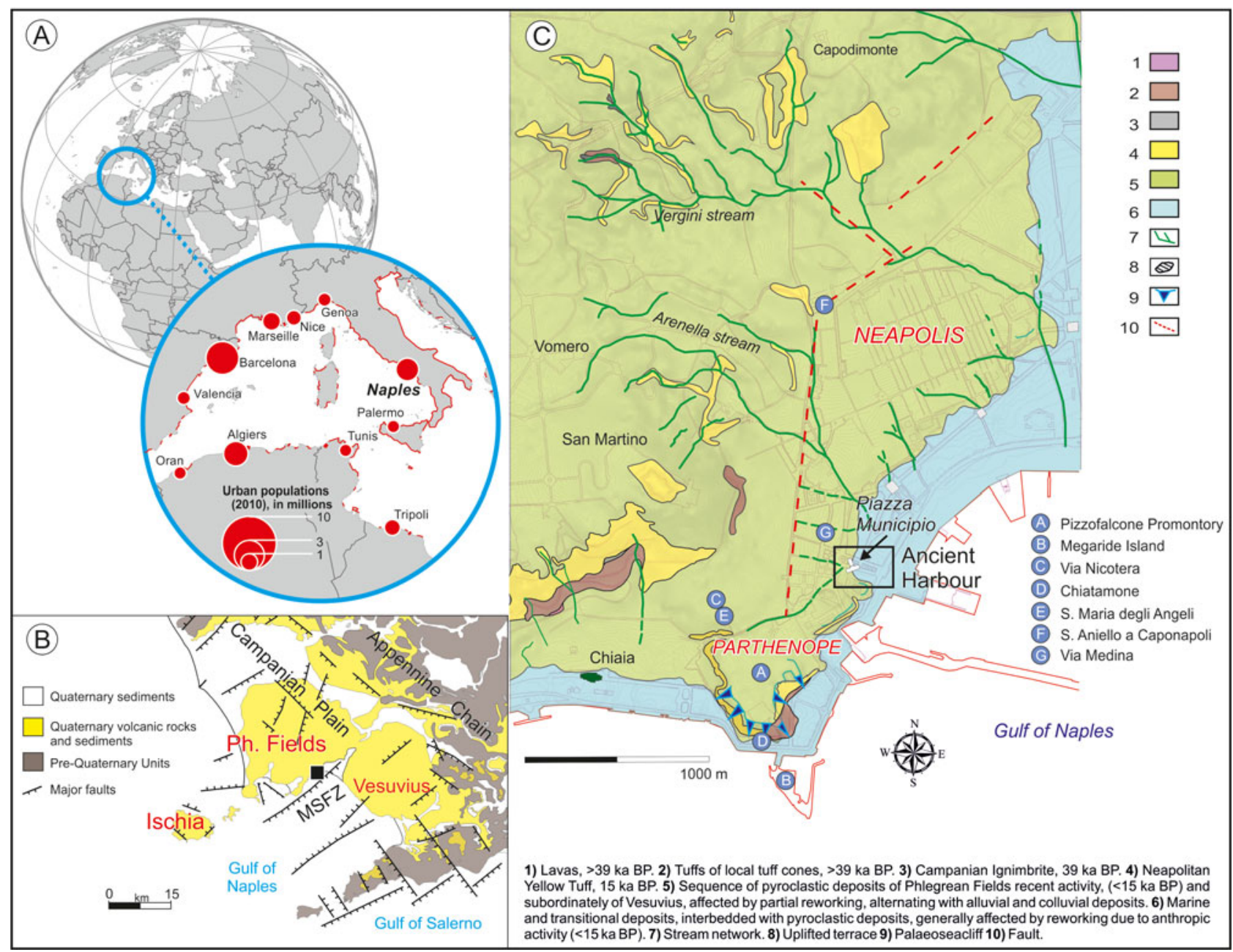

Figure 1. (A) Geographic location of Naples and populations of some key coastal conurbations of the western Mediterranean. The red line indicates hot spots of coastal risk (after Satta et al., 2017). (B) Simplified geologic and tectonic setting of the Gulf of Naples and its hinterland. The black square denotes the location of the study area. MSFZ, Magnaghi-Sebeto Fault Zone; Ph. Fields, Phlegrean Fields. (C) Geomorphological and archaeological setting of Parthenope and Neapolis. The box indicates the location of the ancient harbour. (For interpretation of the references to colour in this figure legend, the reader is referred to the web version of this article.)

geologic and archaeological evidence in urban contexts represents one of the most promising branches of geoarchaeological research (Butzer, 2008; Bini et al., 2018). Archaeological remains of harbours and maritime structures have been shown to be important archives of past variations in RSL (e.g., Morhange et al., 2001; Anzidei et al., 2014; Benjamin et al., 2017), notably for the last three millennia (e.g., Galili et al., 1988; Lambeck et al., 2004; Fontana et al., 2017).

The construction of the new Naples underground railway, with a focus on the Piazza Municipio site (Fig. 1C), offered the possibility to study well-preserved harbour structures, often showing fossil traces of biological indicators of past sea levels (e.g., Morhange et al., 2001; Morhange and Marriner, 2015; Rovere et al., 2015). These proxies were married with new and previously published biostratigraphic data (Liuzza, 2014; Di Donato et al., 2018), providing fresh insights into the RSL history of this extremely complex coastal area.

\section{STUDY AREA}

\section{Geomorphological and tectonic setting}

The city of Naples (Italy) constitutes one of the largest coastal conurbations in the western Mediterranean (Fig. 1A; Satta et al., 2017). Its coastal geomorphology is mainly characterized by rocky cliffs and small pocket beaches alternating with densely populated coastal plains (Fig. 1C). This area has a microtidal regime, with a tidal range of $\pm 0.2 \mathrm{~m}$ (Naples Tidal Station; https://www.mareografico.it [accessed 28/11/ 2018]).

The modern city lies on the westernmost margin of one of these coastal plains (the Campanian Plain) and encompasses a wide area of active volcanism and tectonics between the eastern edge of the nested caldera of the Phlegrean Fields and the Vesuvius stratovolcano apron (Fig. 1B; Di Vito et al., 1999; Milia and Torrente, 2003; Aucelli et al., 2017b). The late Pleistocene and Holocene activity of these 
two volcanic complexes led to the deposition of thick tuff deposits and sequences of pyroclastic fallout and density current deposits (Di Vito et al., 1999; Milia et al., 2006).

The Campanian Plain is developed on top of a 3-km-thick sedimentary sequence filling a Quaternary tectonic depression known as the Campanian Plain Graben (Santangelo et al., 2017). This plain and its offshore extension have experienced continuous subsidence during the entire Quaternary, at an average rate of $\sim 2 \mathrm{~mm} / \mathrm{yr}$ (Santangelo et al., 2017).

The morphology of the city has been significantly controlled by late Quaternary volcanic activity, with a major role played by the Phlegrean Fields (e.g., Aiello and Marsella, 2015; Aucelli et al., 2017b). The current landscape is the result of the mantling of preexisting volcanic edifices by the Neapolitan Yellow Tuff (NYT; 15 ka; Deino et al., 2004), the collapse of the related caldera (Phlegrean Fields depression), and, between 15 and $3.8 \mathrm{ka}$, of the explosive activity of at least 70 monogenetic volcanoes, which generated tuff cones, tuff rings, and widespread Plinian deposits (e.g., Di Vito et al., 1999; Milia and Torrente, 2003).

The intense volcano-tectonic activity also resulted in a number of fault scarps (mainly southwest-northeast and northwest-southeast) that are widespread across the study area (e.g., Orsi et al., 2004; Cinque et al., 2011; Romano et al., 2013; Fig. 1B), including within the Phlegrean Fields caldera, in the Gulf of Naples, and the Campanian Plain (Di Vito et al., 1999; Bruno et al., 2003; Cinque et al., 2011). A major fault zone (the Magnaghi-Sebeto Fault Zone [MSFZ], Fig. 1B; Bruno et al., 2003), occurs in the mid- to northern portion of the gulf with alternating northeast-southwest and east-west trending segments. The MSFZ bounds the subsiding Sebeto Plain, where subsidence rates of $1.5-2 \mathrm{~mm} / \mathrm{yr}$ have been estimated for the late Holocene (Cinque et al., 2011; Aucelli et al., 2019).

\section{Archaeological setting}

In the Naples area, evidence for human occupation dates back to the late Neolithic and the Eneolithic period (Giampaola and Boenzi, 2013), as indicated by a sequence of plow zones associated with traces of human occupation, which was found intercalated in volcanic deposits attributed to the Pigna S. Nicola (9.2-9.5 ka) and Agnano-Monte Spina (4.5-4.6 ka) eruptions (Di Vito et al., 1999; Smith et al., 2011).

There is evidence for the occupation of a large coastal area west of Pizzofalcone promontory, on the Castel Nuovo heights and at the margin of the Neapolis plateau (Fig. 1C) in the Early Bronze Age (twenty-first century to twentieth century BC, 4.0 to $3.9 \mathrm{ka}$ ). Despite the interruption caused by the Pomici di Avellino eruption (twentieth century BC), which largely concerned the Naples area, evidence of a persistent coastal occupation was also found in the Middle Bronze Age (seventeenth century to fourteenth century BC, 3.6 to $3.3 \mathrm{ka}$ ) and, at some sites, until the Late Bronze Age (Giampaola and Boenzi, 2013; Romano et al., 2013; Di Vito et al., 2019). However, the most important coastal occupation of the area started in the eighth century to seventh century BC (2.6-2.7 ka), when Greek colonists founded an epineion (harbour) named Parthenope. This was placed at the foot of San Martino hill, on the promontory of Pizzofalcone and on the Megaride island (Fig. 1C): the only archaeological evidence for this ancient centre is the necropolis of via Nicotera and the ceramic material of Chiatamone and the S. Maria degli Angeli dump (end of the eighth century to fifth century BC; 2.7-2.4 ka; Cinquantaquattro, 2015; Giampaola, 2017; Fig. 1C). Parthenope survived as a minor centre named Palaepolis (old-polis) until the fourth-third centuries BC (2.3-2.2 ka). At the end of the sixth to the beginning of fifth century BC ( $2.5 \mathrm{ka})$, a new-polis, Neapolis, was founded at the eastern edge of Parthenope (e.g., D'Agostino and Giampaola, 2005) on a gently sloping and rounded plateau (Fig. 1C). Neapolis developed continuously from the end of the sixth century BC $(\sim 2.5 \mathrm{ka})$ to the end of the fifth century $\mathrm{AD}(\sim 1.5 \mathrm{ka})$.

Reconstruction of the ancient coastal landscape revealed the presence of a bay between Neapolis and Parthenope (Carsana et al., 2009; Liuzza, 2014; Di Donato et al., 2018). On the margin of this bay, a sheltered basin existed in the area between Piazza Municipio and Via Medina (Fig. 1C). The archaeological excavations of the Municipio underground station (Fig. 1C) clearly indicated the presence of the ancient harbour since at least the third century BC $(\sim 2.2 \mathrm{ka})$, when intensive dredging of the sea bottom (Fig. 2A) removed almost all the older sediments and the first maritime structures were built (e.g., Giampaola and Carsana, 2005; Carsana et al., 2009; Morhange and Marriner, 2010). However, the recovery of residual ceramics dated to the eighth and seventh centuries BC (2.7-2.6 ka), as well as the presence of nondredged marine sediments, dated from the end of sixth to the end of fifth century BC (2.5$2.4 \mathrm{ka}$ ), suggest that the area of Piazza Municipio was already used as a harbour at the time of Parthenope and at the foundation of Neapolis (Giampaola, 2017). Many buried harbour structures (i.e., piers, quays, ramps, and walls; Fig. 2A and B) were discovered during archaeological excavations, often including fossil remains of biological indicators attached to former structures (Liuzza, 2014; Di Donato et al., 2018). The Piazza Municipio excavation further revealed a unique series of shipwrecks dated to the second century $\mathrm{BC}$ (2.1 ka), wrecks $\mathrm{E}$ and $\mathrm{H}$ in Figure $2 \mathrm{~A}$; the end of the first century AD (1.9 ka), wrecks A and C, in Figure 2B; and the end of the second century/beginning of the third century $\mathrm{AD}(1.8$ ka), wrecks B, F, and G, in Figure 2B (Giampaola et al., 2006; Boetto, 2009; Boetto and Poveda, 2018).

\section{METHODS}

\section{RSL proxies}

The accuracy of the RSL reconstruction using coastal archaeological remains depends on understanding the relationship between the coastal structure and the contemporary mean sea level (msl; e.g., Morhange and Marriner, 2015), which 

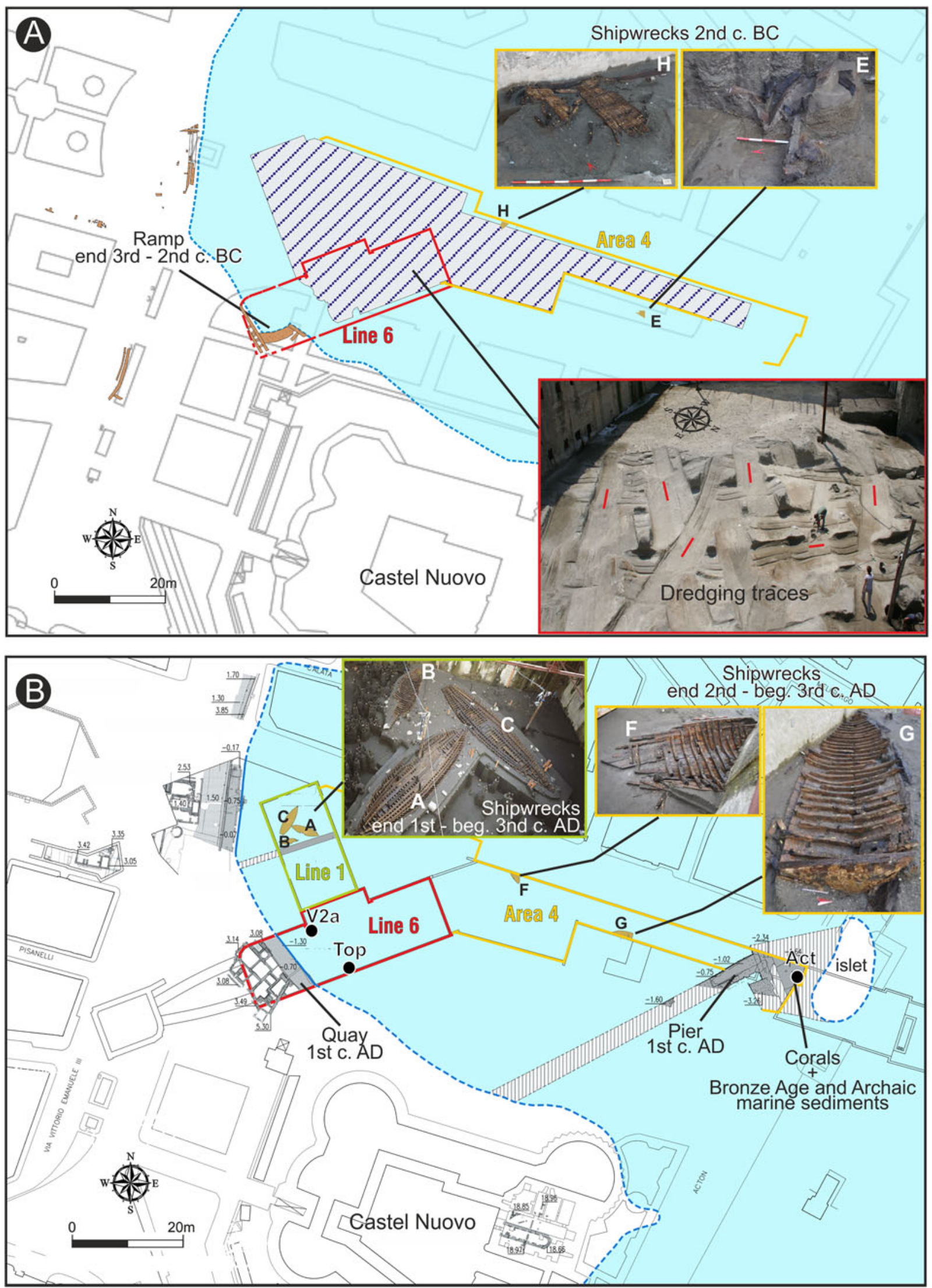

Figure 2. (A) Main archaeological findings of the Hellenistic period. The position of the ramp is indicated together with details of the dredging operations (after Di Donato et al., 2018). (B) Main archaeological findings of the Roman period. The position of the pier and the quay are indicated together with the location of the first- and second-century AD shipwrecks (after Di Donato et al., 2018). Black dots indicate the location of the sections V2a, Top and Act. (see Fig. 4). Photo credits: the Soprintendenza Archeologia, Belle arti e Paesaggio per il comune di Napoli. The reconstructed palaeo shoreline (blue dashed line) and the palaeo marine basin of the harbour (blue shaded area) are also shown. (For interpretation of the references to colour

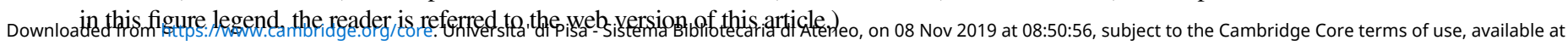
https://www.cambridge.org/core/terms. https://doi.org/10.1017/qua.2019.60 
significantly improves when fossil remains of attached biological indicators are present (e.g., Laborel and LaborelDeguen, 1994; Morhange et al., 2001; Morhange and Marriner, 2015). Several studies have demonstrated that a precise analysis of the biological zone (cf. Laborel and LaborelDeguen, 1994) found on archaeological structures may lead to a very precise assessment (up to $\pm 0.1 \mathrm{~m}$ ) of the former RSL (e.g., Morhange et al., 2001, 2013; Morhange and Marriner, 2015).

In this study, we analysed the biological assemblages found on harbour structures. These assemblages are composed of encrusting species such as vermetids and Ostrea spp. The upper limit of the living zone of these species delineates the biological mean sea level (bmsl; Morhange and Marriner, 2015; Rovere et al., 2015). The bmsl is not a perfect horizontal line but is naturally warped, even over short distances, because of local variations in hydrodynamics and morphology (Vacchi et al., 2016). However, in the microtidal Mediterranean setting, bmsl occupies the lower part of the tidal range (i.e., from mean low water [MLW] to the msl; Laborel and Laborel-Deguen, 1994; Rovere et al., 2015). For this reason, these biological markers are often used to produce very accurate RSL index points (i.e., a point that constrains the palaeo-RSL in space and time; van de Plassche, 1982), notably in the Mediterranean Sea (Morhange et al., 2001, 2013; Vacchi et al., 2018).

Following Shennan et al. (2015), we estimated the palaeo-RSL position according to the following equation:

$$
R S L_{i}=A_{i}-R W L_{i}
$$

where $A$ is the elevation of the sample $i$, and $R W L$ is the reference water level (i.e., the midpoint of the indicative range of the sample $i$; see Table 1).

Apart from the sediments and structures of the Hellenistic and Roman harbour, marine sands overlying the tufaceous bedrock and related to ancient marine bottoms were identified between 5.1 and $3.7 \mathrm{~m}$ below msl (Giampaola, 2018). These sediments were investigated by means of an integrated approach including granulometric and palaeontological analyses, which allowed us to define the depositional environments. In particular, the palaeoecological interpretation of fossil assemblages was based on the present ecology of the identified mollusk taxa. A more detailed description of these methodologies is provided in Di Donato et al. (2018). The marine biofacies do not represent an accurate RSL proxy because they can only constrain the RSL above a datum. However, they can be transformed into marine limiting points to help probe changes in RSL through time and to estimate the directions and the rates of these changes (Shennan et al., 2015).

\section{Chronological constraints}

The age of both RSL index and limiting points is constrained by the archaeological dating of both the harbour structures (Boetto et al., 2010; Giampaola, 2017) and the sedimentary units (Di Donato et al., 2018). The latter is based on the archaeological content (mainly pottery) of the marine/lagoon sequences found in the harbour basin. This pottery is often well preserved and comprises goods and ship equipment lost during loading and unloading operations in the harbour, in addition to waste from the surrounding urban area (Di

Table 1. Index and limiting points used to reconstruct the relative sea-level (RSL) evolution of the ancient harbour of Naples. The stratigraphic age is given by the archaeological content of the deposit. The calibration of the ${ }^{14} \mathrm{C}$ age of the Balanophyllia sp. samples was performed using the $\Delta \mathrm{R}$ value of $69 \pm 40$ (Siani et al., 2000). IR, indicative range; MHW, mean high water; MLW, mean low water; msl, mean sea level.

\begin{tabular}{|c|c|c|c|c|c|c|c|c|}
\hline Evidence & $\begin{array}{l}\text { Type of } \\
\text { dating }\end{array}$ & $\begin{array}{l}\text { Age cal } \\
(\mathrm{BC} / \mathrm{AD})\end{array}$ & $\begin{array}{c}\text { Elevation } \\
(\mathrm{m} \mathrm{msl})\end{array}$ & $\begin{array}{l}\text { Elevation } \\
\text { error }(\mathrm{m})\end{array}$ & IR & $\begin{array}{l}\mathrm{RSL} \\
(\mathrm{m})\end{array}$ & $\begin{array}{l}\text { Error } \\
(\mathrm{m})\end{array}$ & Type \\
\hline $\begin{array}{l}\text { Balanophyllia sp. } \\
\text { (DSH7335_SH) }\end{array}$ & $\begin{array}{l}\text { Radiocarbon age } \\
\qquad\left(3990 \pm 31{ }^{14} \mathrm{C} \text { yr BP }\right)\end{array}$ & $1961 \pm 157 \mathrm{BC}$ & -4.60 & 0.05 & Below msl & $>-4.6$ & 0.05 & $\begin{array}{l}\text { Marine limiting } \\
\text { point }\end{array}$ \\
\hline $\begin{array}{l}\text { Balanophyllia sp. } \\
\text { (Poz-3066) }\end{array}$ & $\begin{array}{l}\text { Radiocarbon age } \\
\qquad\left(3890 \pm 35{ }^{14} \mathrm{C} \text { yr BP }\right)\end{array}$ & $1818 \pm 150 \mathrm{BC}$ & -4.50 & 0.05 & Below msl & $>-4.5$ & 0.05 & $\begin{array}{l}\text { Marine limiting } \\
\text { point }\end{array}$ \\
\hline Marine deposit & Stratigraphic age & $1450 \pm 150 \mathrm{BC}$ & -4.25 & 0.05 & Below msl & $>-4.25$ & 0.05 & $\begin{array}{l}\text { Marine limiting } \\
\text { point }\end{array}$ \\
\hline Marine deposit & Stratigraphic age & $450 \pm 50 \mathrm{BC}$ & -3.70 & 0.05 & Below msl & $>-4.5$ & 0.05 & $\begin{array}{l}\text { Marine limiting } \\
\text { point }\end{array}$ \\
\hline $\begin{array}{l}\text { Ostrea sp. on Hellenistic } \\
\text { ramp }\end{array}$ & $\begin{array}{l}\text { Stratigraphic age and } \\
\text { ramp age }\end{array}$ & $150 \pm 50 \mathrm{BC}$ & -2.10 & 0.05 & $\begin{array}{l}\text { MLW to } \\
\text { msl }\end{array}$ & -2.0 & 0.1 & Index point \\
\hline $\begin{array}{l}\text { Erosional mark on the } \\
\text { Augustean pier }\end{array}$ & Harbour age & $\mathrm{AD} 50 \pm 50$ & -1.60 & 0.1 & $\begin{array}{l}\text { MHW to } \\
\text { MLW }\end{array}$ & -1.6 & 0.2 & Index point \\
\hline $\begin{array}{l}\text { Upper limit of Ostrea sp. } \\
\text { and vermetids }\end{array}$ & Stratigraphic age & $\mathrm{AD} 425 \pm 25$ & -1.60 & 0.05 & $\begin{array}{l}\text { MLW to } \\
\text { msl }\end{array}$ & -1.5 & 0.1 & Index point \\
\hline Beachface deposit & Stratigraphic age & $\mathrm{AD} 550 \pm 50$ & -1.30 & 0.1 & Above msl & $<-1.3$ & 0.1 & $\begin{array}{l}\text { Terrestrial } \\
\text { limiting point }\end{array}$ \\
\hline Upper limit of Ostrea sp. & Stratigraphic age & $\mathrm{AD} 1250 \pm 50$ & -0.70 & 0.05 & $\begin{array}{l}\text { MLW to } \\
\text { msl }\end{array}$ & -0.6 & 0.1 & Index point \\
\hline
\end{tabular}


Donato et al., 2018). The chronological error associated with this kind of material ranges between 50 and $100 \mathrm{yr}$.

In order to improve the chronology, we acquired two new ${ }^{14} \mathrm{C}$ dates on in situ fossil corals (Balanophyllia spp.) found at the base of the stratigraphic sequence. These corals were in living position on the tufaceous bedrock. The samples were calibrated using CALIB 7.1 (Stuiver et al., 2019) and the Marine13 calibration curve (Reimer et al., 2013) with a $\Delta R$ of $69 \pm 40$ (Siani et al., 2000). All vertical measurements were undertaken using a Leica DGPS (differential GPS) relative to the current $\mathrm{msl}$ with a precision of $0.05 \mathrm{~m}$.

\section{Isostatic and tectonic contributions to the RSL record}

For the late Holocene period (i.e., last $4.0 \mathrm{ka}$ ), the iceequivalent meltwater is either zero or minimal (Milne et al., 2005; Church et al., 2008). Therefore, changes observed in RSL are dominated by vertical land movements because of glacio- and hydro-isostatic adjustment (GIA). In tectonically active areas, the GIA related land-level changes can be accentuated or counterbalanced by ground movements (e.g., Anzidei et al., 2014; Vacchi et al., 2014; Kolaiti et al., 2017)

In order to better quantify these vertical components, we compared the reconstructed RSL record with the following GIA predictions available for the Gulf of Naples: (1) the ICE-5 G VM2 (Peltier, 2004) GIA prediction computed in Vacchi et al. (2016) using the "sea-level equation" solver SELEN (Spada and Stocchi, 2007); and (2) the K33_j1b_WS9_6 GIA prediction computed in the Gulf of Naples by Lambeck et al. (2011). This comparison allowed us to factor-out the GIA-related land-level changes from the reconstructed RSL history in order to assess the role of tectonic contributions for different historical periods.

\section{RESULTS}

The archaeological findings (Fig. 3) coupled with the analysis of sedimentary sequences and microfaunal remains (Lines 1 and 6 and Area 4, Fig. 2A and B; Fig. 4) have yielded evidence for $\sim 4000$ yr of RSL evolution at the Piazza Municipio site. The results are presented in chronological order from the oldest to the most recent.

\section{Bronze Age period}

The rocky seafloor outcrops at the base of the sedimentary sequence of the harbour basin. It is composed of yellow tuff and is widely colonized by benthic species including bivalves, corals, and serpulids. At 4.6 and $4.5 \mathrm{~m}$ below msl, two corals (Balanophyllia sp.) were found in living position on rocky outcrops (Fig. 4). This coral, widespread in the Mediterranean, is typical of the upper infralittoral zone (Goffredo et al., 2004). The two samples yielded very coherent ages of $1961 \pm 157$ and $1818 \pm 150$ cal yr BC (approximately twentieth century to approximately nineteenth century BC, the final phase of the Early Bronze Age; Table 1). Marine sediments overlie the basal rocky seafloor until $4.25 \mathrm{~m}$ below msl. These comprise coarse-to-medium, poorly sorted sands characterised by a slight fining upward trend. Benthic foraminifera assemblages are mostly represented by taxa that are presently widespread in infralittoral vegetated seafloors of the Gulf of Naples (Sgarrella and Moncharmont-Zei, 1993) such as Cibicides lobatulus, Elphidium crispum, Elphidium macellum, Rosalina spp., and, among the miliolids, Quinqueloculina pseudobuchiana, Miliolinella spp., and Siphonaperta spp. Vermetids are also abundant in the wash residues. The abundance of archaeological material allowed these infralittoral units to be attributed to the Middle Bronze Age (MBA 1-2 and 3, sixteenth to fourteenth centuries BC; Table 1).

\section{Greek period}

A further marine unit overlies the MBA sediments up to $3.7 \mathrm{~m}$ below msl. This unit, similar to the MBA unit in grain size and faunal assemblages, showed an upwards coarsening trend. The dating of the archaeological material found in this unit yielded Archaic ages (end of the sixth century to end of the fifth century BC; Table 1). This implies an $\sim 800 \mathrm{yr}$ gap (from 1300 to $500 \mathrm{BC}$ ) in sedimentation in this marine unit (Fig. 4). The causes of this hiatus are unclear (see Discussion section) but could be ascribed to drift erosion.

At about $2 \mathrm{~m}$ below msl, the first large archaeological harbour structure was observed. This is a gently sloping surface that is $\sim 12 \mathrm{~m}$ long and made of squared blocks (Figs. 2A and $3 \mathrm{~A})$. The top and the bottom of this structure are placed at $1.53 \mathrm{~m}$ and at $2.25 \mathrm{~m}$ below msl, respectively. This structure, composed of large tuff blocks, lies on a sandy bottom containing marine-shell remains, Posidonia oceanica seagrass, and ceramic fragments (Fig. 3A). The archaeological excavation indicates that this structure was in use during the Hellenistic period (end of the third century to second century $\mathrm{BC}$; Table 1) and was likely used as a ramp or slipway. The maritime characteristics of this structure are further attested by fossil remains of Ostrea spp. found at its seaward end (Fig. 3A). The upper limit of the marine shell encrustation was measured at $2.1 \mathrm{~m} \pm 0.05 \mathrm{~m}$ below $\mathrm{msl}$ and is buried by late third-century BC sands. The remains of two Hellenistic shipwrecks were also found lying on the seabed of the bay (Fig. 2A).

\section{Roman period}

In the first century AD, several large harbour structures were built to serve the rapidly expanding Roman Naples. These infrastructures were intended to provide a better-protected cove in order to improve accessibility and navigability. At that time, the seafloor reached maximal depths of 5 to $6 \mathrm{~m}$, as testified by evidence for dredging of the tufaceous substrate (NYT). A small islet at the cove entrance (Fig. 2B) was used as a base for a large pier (Fig. 3B) that was probably built to protect the internal part of the harbour from the southern 


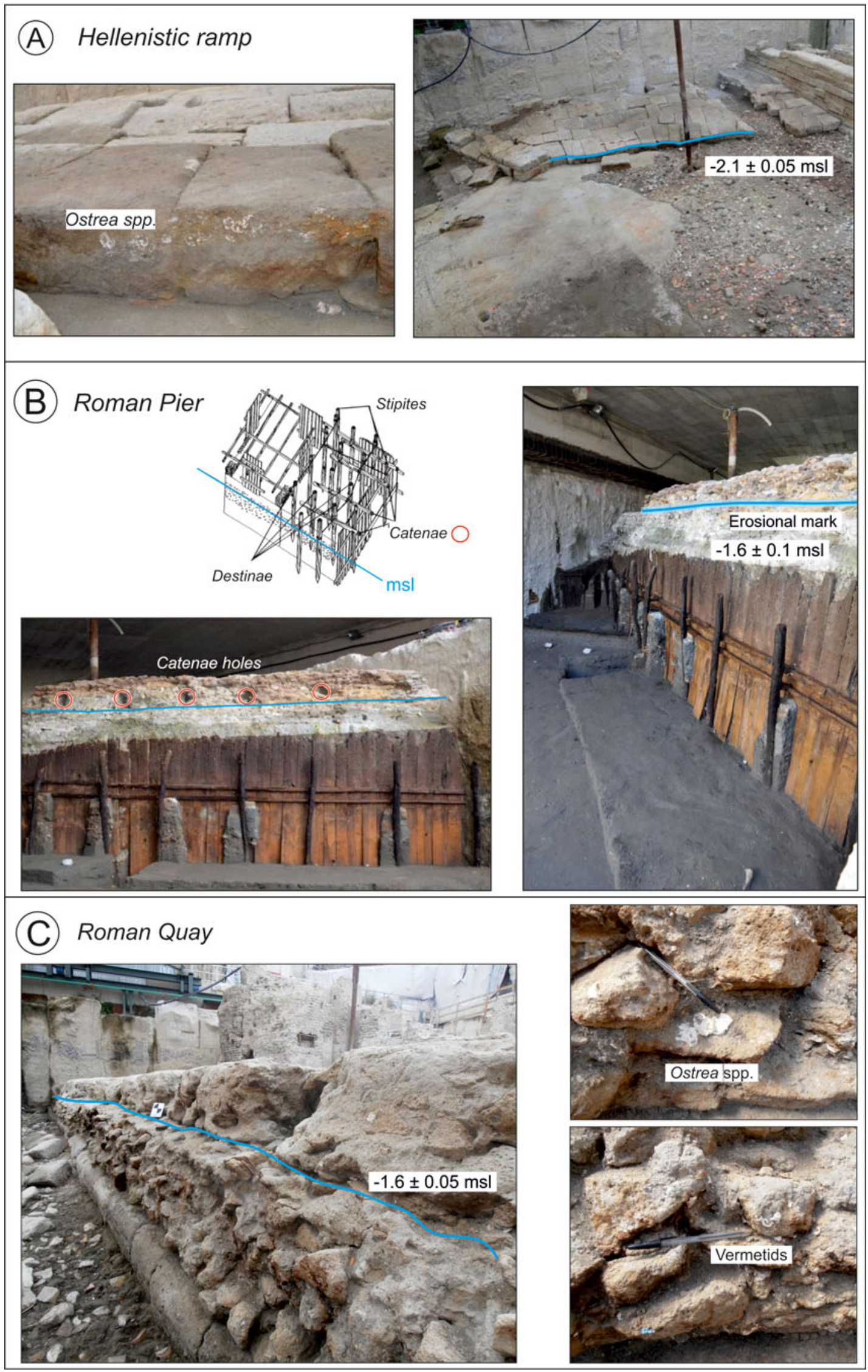

Figure 3. (A) Upper limit (blue line) of fixed biological indicators (Ostrea spp.) found on the Hellenistic ramp. (B) Positions of the erosional mark (blue line) and the catenae holes (red circles) on the Augustan pier. The panel also shows the general formwork of Roman concrete harbours (after Felici, 1998). (C) Upper limit (blue line) of fixed biological indicators (Ostrea spp. and vermetids) found on the Roman quay. msl, mean sea level. Photo credits: the Soprintendenza Archeologia, Belle arti e Paesaggio per il comune di Napoli. (For interpretation of the ref- 


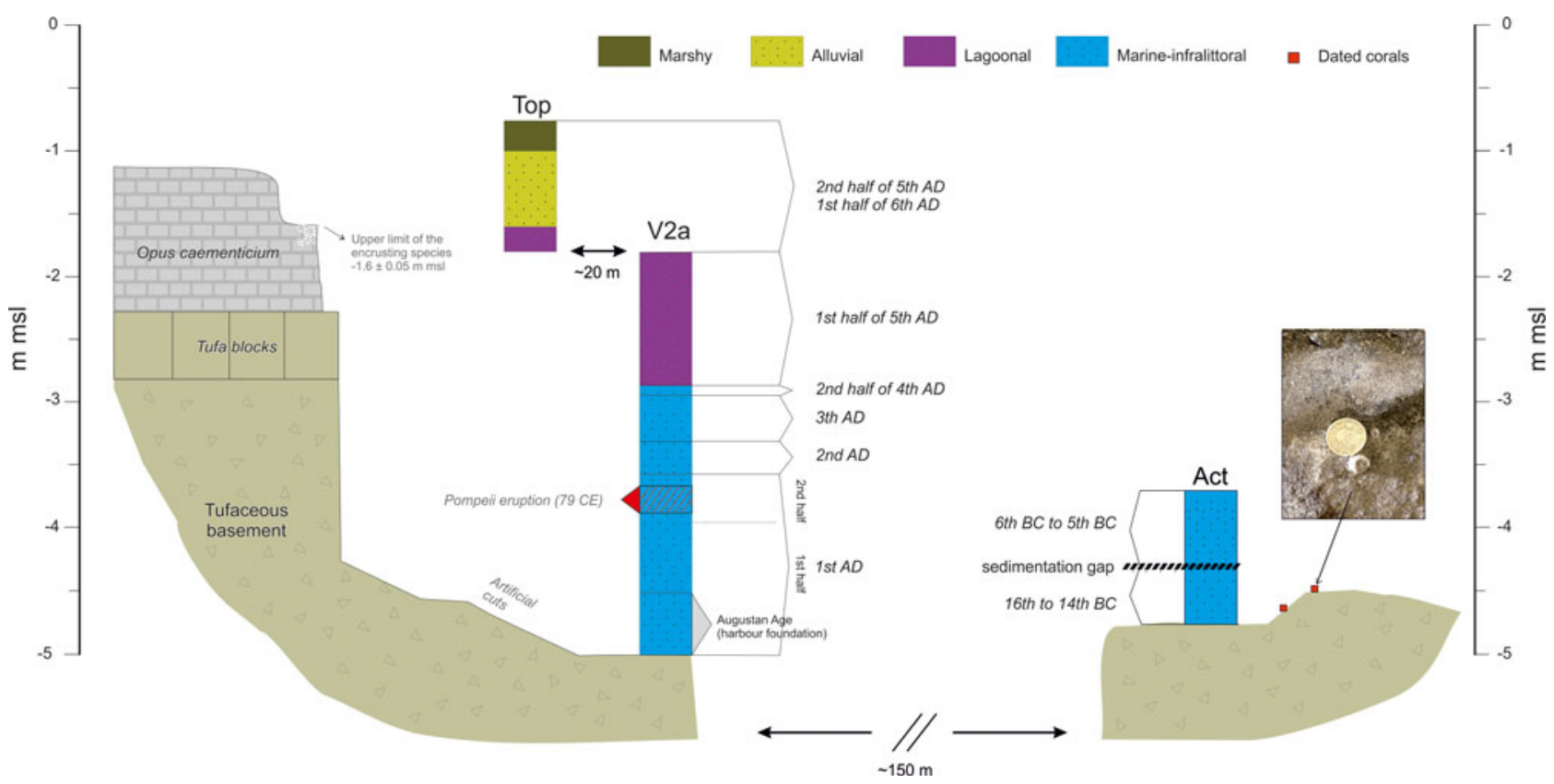

Figure 4. (colour online) Chronostratigraphic sequence of the palaeoenvironments elucidated in the Act, V2a, and Top sections. See Figure 2B for the location of the sections in the Naples harbour basin. msl, mean sea level.

swell. In the western part of the cove, a perfectly preserved quay was also found (Figs. 2B and 3C).

The low-energy harbour environment has recorded the progressive silting of the basin. The marine stratigraphy (Fig. 4), precisely dated using the archaeological content (mainly pottery), yielded ages ranging from the Augustan (end of the first century $\mathrm{BC}$ to beginning of the first century $\mathrm{AD}$ ) to the late Roman periods (fifth century AD; Di Donato et al., 2018). Additional chronological constraints were provided by five shipwrecks found in the harbour basin (Boetto et al., 2010, Boetto and Poveda, 2018). They were dated from the end of the first to the beginning of the third century $\mathrm{AD}$ (Fig. 2B).

\section{The concrete pier}

On the southeastern side of the harbour basin, the remains of an impressive pier, $\sim 360 \mathrm{~m}^{2}$ in area and composed of two arms, was observed (Fig. 2B). The pier was built using a wooden frame filled with opus caementicium (hydraulic cement; Brandon et al., 2014). Its top was measured from 0.7 to $1.15 \mathrm{~m}$ below msl. The lower part of the pier, at $4 \mathrm{~m}$ below msl, shows the preserved wooden planks (stipites) of the formwork wedged in sandy sediments dated to the second half of the first century BC (Table 1).

In the concrete infilling, above the stipites, holes testify to the presence of catenae (Fig. 3B). Above each of the stipites, holes hosting the catenae are observed (Fig. 3B). Catenae are horizontal wooden beams that were used to contain the external thrusts during harbour construction and, notably, during the consolidation phase of the hydraulic cement (Felici, 1998; Brandon et al., 2014). About $10 \mathrm{~cm}$ below the catenae holes, a long and continuous erosional mark can be observed along the whole length of the pier. It has a generally horizontal shape and was measured at $1.6 \pm 0.1 \mathrm{~m}$ below msl (Fig. 3B).

On the western side of the harbour basin, a large quay, $\sim 24.5 \mathrm{~m}$ long and $\sim 6.5 \mathrm{~m}$ wide, was found (Fig. $2 \mathrm{~B}$ ). The quay is made of opus caementicium overlying one or two rows of large tuff blocks placed directly above the tuff substrate (Fig. 3C). The top of the quay (the walkable surface) is not uniform and was measured at elevations ranging between 0.8 and $1.2 \mathrm{~m}$ below $\mathrm{msl}$. The base of the quay lies in direct contact with the tuff substrate. Below this, evidence of artificial scars cut into the tufaceous substrate was observed down to $5 \mathrm{~m}$ below msl, close to the quay. These scars are coeval with the foundation of the quay, as robustly demonstrated by the thick $(\sim 1.4 \mathrm{~m})$ sedimentary layer, which was found above the top of the hand-cut tuff substrate (Fig. 4). The multiproxy analysis of the lowest part of the stratigraphic sequence (Di Donato et al., 2018; Fig. 4) indicates an infralittoral environment dated to the first century AD (Table 1). At $3.85 \mathrm{~m}$ below msl, this unit is abruptly truncated by a pyroclastic layer, $0.2 \mathrm{~m}$ thick, associated with the AD 79 Pompeii eruption (Di Donato et al., 2018).

Above this layer, another marine infralittoral sequence (Liuzza, 2014; Di Donato et al., 2018) develops for $\sim 0.75 \mathrm{~m}$. This sequence, extremely rich in archaeological remains, was dated from the end of the second century to the end of the fourth century AD. At $2.8 \mathrm{~m}$ below msl, a transition to a shallow water lagoon environment is indicated by both a decrease in the sediment grain size and by a sudden increase in lagoon microfauna (Di Donato et al., 2018). This unit was dated to the first half of the fifth century AD, and its top was measured at $1.8 \mathrm{~m}$ below msl (Liuzza, 2014; Di Donato et al., 2018). 
On the quay structure, a significant population of encrusting fossil species (mainly Ostrea and vermetids; Fig. 3C) was observed (Liuzza, 2014). They are widespread on the archaeological structure, and their upper limit (Fig. 3C) was measured at $1.60 \pm 0.05 \mathrm{~m}$ below msl. The colonization by this attached marine organism was interrupted by the progressive silting of the quay area, before being sealed by sediments dated to the first half of the fifth century AD (Table 1).

\section{Late Roman and medieval periods}

The Roman harbour basin shows evidence for progressive silting throughout antiquity. During the excavation, the quay structure was found covered by a sandy to gravelly beach deposit rich in marine-shell debris (mainly Loripes lucinalis, Paphia aurea, Bittium reticulatum, Tapes decussatus, and Cerithium vulgatum) mixed with abundant vegetal remains (e.g., nutshells, almonds, and seeds; Liuzza, 2014). Furthermore, this deposit is full of anthropogenic remains such as ceramics and glass fragments, pieces of mosaic, and traces of iron and lead (Liuzza, 2014). In some cases, the sandy sediments show plane parallel bedding or a foreset stratification. This palaeobeach was archeologically dated to the end of the fifth century to the beginning of the sixth century $\mathrm{AD}$ (Table 1) and was found at elevations of $1 \pm 0.2 \mathrm{~m}$ below msl (Liuzza, 2014). A further indicator of the late-Roman evolution of the harbour basin is the presence, in Line 6 of the excavation area (Fig. 2B), of a beachface deposit at $1.3 \pm 0.2 \mathrm{~m}$ below msl. This deposit, dated to the sixth century $\mathrm{AD}$ (Table 1), is bordered by small juniper trees (Juniperus spp.) found in living position (Barone, M.R., University of Naples, personal communication) and extending for about $13 \mathrm{~m}$.

Finally, on the top portion of the Roman pier (Fig. 2B), there is evidence of biological encrustations (mainly Ostrea sp.) up to $0.7 \mathrm{~m}$ below msl. These encrustations continued to colonize the structure after the end of the operational period. They were sealed by sediments dating to the thirteenth century to fourteenth century AD (Table 1).

\section{DISCUSSION}

\section{New constraints on the RSL history of the ancient harbour of Naples}

The multiproxy analysis of sediments from the ancient Gulf of Naples provides new constraints on the RSL evolution of the area (Fig. 5). Between $\sim 2000$ and $\sim 500 \mathrm{BC}$, the RSL is loosely constrained by the sole presence of marine limiting points. The oldest data, represented by the fossil corals, constrain the RSL position to above $\sim 4.5 \mathrm{~m}$ below $\mathrm{msl}$ at $\sim 1800$ BC (Fig. 5).

The benthic assemblages of the overlying infralittoral marine sediments testify to the occurrence of seafloors with Posidonia oceanica meadows throughout the Bronze and Archaic Age periods. The living range of this endemic
Mediterranean seagrass is wide ( 0 to $40 \mathrm{~m}$ below $\mathrm{msl}$; Vacchi et al., 2017), and therefore, these marine sediments only constrain the RSL above $4.25 \mathrm{~m}$ below msl at $\sim 1400 \mathrm{BC}$ and above $3.7 \mathrm{~m}$ below msl at $\sim 500 \mathrm{BC}$ (Fig. 5). It is worth noting the absence of sedimentation between the fourteenth century and the sixth century BC. The causes of this $\sim 800$ yr hiatus are unclear. A possible explanation may be related to the position of this sedimentary sequence, which is located in the most external part of the basin, near the small rocky islet (Fig. 2B). Changes in the nearshore hydrodynamics, triggered by the period of increased Mediterranean storminess recorded between $\sim 1600$ and $\sim 600$ BC (e.g., Sabatier et al., 2012; Marriner et al., 2017), may have produced increased erosion in the outer part of the basin. However, this hypothesis requires more detailed investigations to understand the environmental setting of the basin before the foundation of the harbour.

The oldest RSL index point is provided by the biological encrustation found on the Hellenistic ramp. In low-energy harbour settings, the upper limit of Ostrea sp. occurs in the lower part of the intertidal zone (MLW to msl, Table 1; Laborel and Laborel-Deguen, 1994; Morhange et al., 2013; Morhange and Marriner, 2015). Once corrected for the indicative meaning, it precisely constrains the RSL position to $2.0 \pm 0.1 \mathrm{~m}$ below msl during the Hellenistic period $(150 \pm 50$ BC; Table 1, Fig. 5).

The majority of the harbour structures are dated to the Roman period. In particular, the quay and the pier are both attributed to the Augustan period (end first century BC beginning first century AD; Giampaola 2017, 2018). The presence of catenae holes $\sim 0.1 \mathrm{~m}$ above well-developed erosional marks, observed along the whole length of the pier, provides insights into the RSL position at the time of the harbour foundation. According to Vitruvius ("de Architectura," $\sim 20$ BC), the catenae (Fig. 3B) were placed slightly above the sea surface (Felici, 1998; Oleson, 1988; Mattei et al., 2018). Thus, these features suggest an RSL position of $1.6 \pm 0.2 \mathrm{~m}$ below msl during the first half of the first century AD (AD $25 \pm 25$; Table 1, Fig. 5).

Furthermore, the thick layer of harbour deposits found above the artificially cut basement in front of the quay (Fig. 4) offers additional insights into the RSL position to the first century AD. These marine sediments are sealed at the top ( $3.65 \mathrm{~m}$ below $\mathrm{msl}$ ) by volcanic ash and marine remains attributed to the Plinian eruption of $\mathrm{AD} 79$. In sum, this represents the harbour seafloor in the second part of the first century AD. The larger sailing ship found in the harbour (Napoli A, Fig. 2B) was $14.25 \mathrm{~m}$ long. If we add this ship draft $(\sim 2 \mathrm{~m})$ to the palaeoseafloor, we obtain a value of $\sim 1.65 \mathrm{~m}$ below msl. The ship draught alone cannot be considered a robust proxy for RSL reconstruction (e.g., Morhange and Marriner, 2015). However, the reconstructed sea-level agrees with the RSL position $(1.6 \pm 0.2 \mathrm{~m}$ below $\mathrm{msl}$ ) indicated by the erosional mark on the pier.

The RSL insights that can be extracted from the analysis of the harbour structures are not limited to the first century AD. On the quay, several traces of encrusting fossil organisms were observed (Fig. 3C). Their upper limit cannot be related 


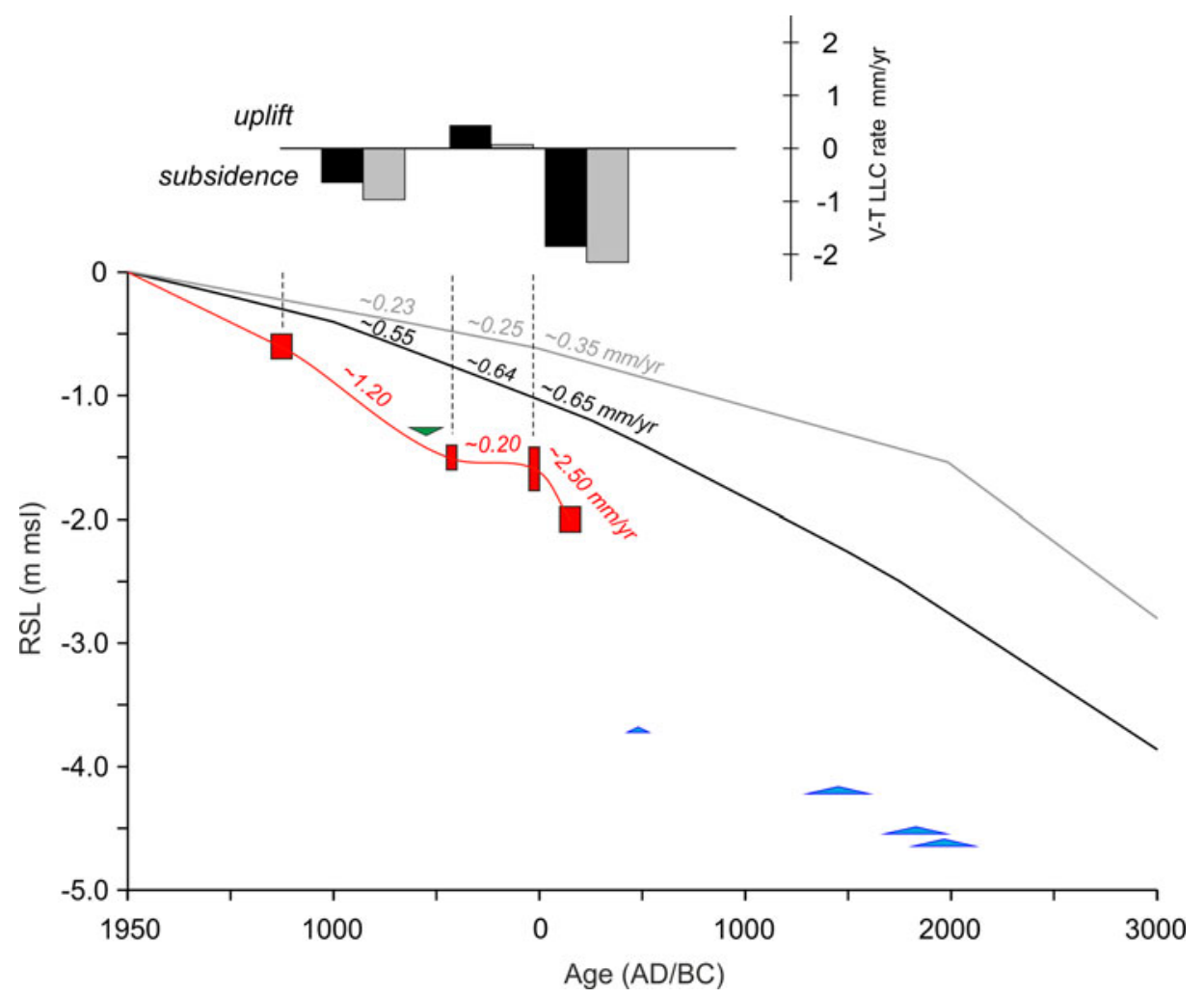

Figure 5. Reconstruction of the relative sea-level (RSL) changes rates in the ancient harbour of Naples. Red boxes are RSL index points, and dark green and blue triangles are terrestrial and marine limiting points, respectively. The dimensions of boxes and lines are based on elevation and age errors. Red line represents the best fit of the RSL index points. Grey and black lines are the glacio- and hydro-isostatic adjustment prediction for the Gulf of Naples according to the ICE-5 G VM2 model (Peltier, 2004) and the K33_j1b_WS9_6 model (Lambeck et al., 2011), respectively. Numbers indicate the average RSL rising rates in the time span delimited by the dashed lines. Histograms represent the net rates of land-level change associated with the volcano-tectonic component (V-T LLC) calculated using the ICE-5 G VM2 model (Peltier, 2004; grey bars) and the K33_j1b_WS9_6 model (Lambeck et al., 2011; black bars). msl, mean sea level. (For interpretation of the references to colour in this figure legend, the reader is referred to the web version of this article.)

to the harbour foundation period because the top of the structure was found sealed by sediments dating to the first half of the fifth century AD. The stratigraphic sequence observed in Piazza Municipio (Di Donato et al., 2018; Fig. 4) documents the progressive silting of the harbour basin between the first century and the sixth century AD. The upper layer of benthic organisms was killed by the progressive reduction of the water column and by deposition of lagoonal sediments that buried the attached bioindicators in the first half of the fifth century AD. Thus, the upper limit of the attached biological indicators, once corrected for the indicative meaning, robustly constrains the RSL to $1.5 \pm 0.1 \mathrm{~m}$ below msl at AD $425 \pm 25$. This RSL position agrees with the coeval supratidal beach evidence, which constrains the RSL to below $1 \pm 0.1$ below msl (Fig. 5).

Similarly, evidence of fossil benthic organisms was observed up to the top of the Augustan pier (i.e., on the walkable surface at $-0.7 \mathrm{~m}$ asl). These fossil biological remains are clearly not related to the functioning period of the pier because the walkable surface of Roman piers was usually at least $0.4 \mathrm{~m}$ above the palaeo-msl (see Auriemma and Solinas, 2009). Furthermore, these biological encrustations are sealed by a stratigraphic unit dated to the thirteenth century to fourteenth century AD. Once corrected for the indicative meaning, this index point constrains the RSL to $0.6 \pm 0.1$ below msl at $\mathrm{AD} 1250 \pm 50$ (Fig. 5).

The new data set of index and limiting points (Table 1, Fig. 5) provides fresh insights into the RSL history of the ancient harbour of Naples during the last $\sim 4 \mathrm{ka}$. Our data show that the total RSL variation was within $4.5 \mathrm{~m}$ below msl. Index points robustly constrain a RSL rise of $\sim 0.5 \mathrm{~m}$ in $\sim 200 \mathrm{yr}$ (Fig. 5, Table 1) at rates of $\sim 2.5 \mathrm{~mm} / \mathrm{yr}$. RSL rates showed a significant deceleration from the first century $\mathrm{AD}$ to the fifth century AD (Fig. 5). During this time period, the RSL stabilized at $1.6 \pm 0.1$ to $1.5 \pm 0.1 \mathrm{~m}$ below msl implying a negligible rate of rise (Fig. 5). Such RSL stabilization ended in the post-Antiquity period. In fact, the youngest index point $(0.6 \pm 0.1 \mathrm{~m}$ below $\mathrm{msl}$ at $\mathrm{AD} \sim 1250$; Table 1) documents the reacceleration of rising rates during the medieval period with rates of $\sim 1.2 \mathrm{~mm} / \mathrm{yr}$ (Fig. 5).

\section{Volcano-tectonic effects on the RSL history of the ancient port of Naples}

As stated previously, for the late Holocene period (i.e., last $4.0 \mathrm{ka})$, the postglacial ice equivalent meltwater input is 
minor (Milne et al., 2005; Khan et al., 2015). Moreover, our suite of RSL index points comprises mostly uncompressible material, rendering the effects of compaction negligible. For these reasons, any change observed in our RSL record is the sum of vertical land movements because of GIA and volcano-tectonics (Ferranti et al., 2010; Cinque et al., 2011; Aucelli et al., 2016). According to the available geophysical models for the Gulf of Naples (e.g., Lambeck et al., 2011; Vacchi et al., 2016; Roy and Peltier, 2018), the GIA contribution should not exceed $\sim 1.1 \mathrm{~m}$ for the last $\sim 2 \mathrm{ka}$ and $\sim 0.4 \mathrm{~m}$ for the last $\sim 1 \mathrm{ka}$. All the RSL index points from the ancient port are placed significantly below both GIA model predictions (Fig. 5), suggesting a general subsidence trend during the last two millennia. This is not surprising because a dominant subsidence trend is reported as the major driver of late Holocene coastal modification around much of the Gulf of Naples (e.g., Cinque et al., 2011; Romano et al., 2013; Aucelli et al., 2017b). However, variability in the RSL rising rates (Fig. 5) was observed at least in the last $\sim 2.2 \mathrm{ka}$ when the RSL evolution is robustly constrained by index points. This variability is controlled by the interplay between volcanic activity of both Phlegrean Fields and the Somma-Vesuvius (Aiello et al., 2001; Milia and Torrente, 2003; Morhange et al., 2006; Aucelli et al., 2017a, 2018b) and the late Quaternary activity of the MSFZ (Fig. 1B; Cinque et al., 2011), which resulted in a variable spatial pattern of late Holocene land-level changes in the different parts of the gulf (Aucelli et al., 2016, 2017b; Mattei et al., 2018).

In order to better quantify the volcano-tectonic component of land-level changes in the area of Piazza Municipio, we factored out the GIA contribution predicted by the two available geophysical models for the Gulf of Naples (see Methods section; Fig. 5). This analysis showed that a period of negative land-level occurred between $150 \pm 50 \mathrm{BC}$ and $\mathrm{AD} 50 \pm 50$ with rates between $\sim 2.15$ and $\sim 1.85 \mathrm{~mm} / \mathrm{yr}$ (Fig. 5 ). On the contrary, land-level changes were negligible or slightly positive $(<\sim 0.5 \mathrm{~mm} / \mathrm{yr})$ during the period between AD $50 \pm 50$ and AD $425 \pm 25$. This triggered a phase of RSL stabilization (Fig. 5) where RSL rose by $\sim 0.2 \mathrm{~mm} / \mathrm{yr}$, which is comparable to the rate predicted by ICE-5 G VM2 and slower than the rate predicted by K33_j1b_WS9_6 (Fig. 5). After AD $425 \pm 25$, land-level changes were once again negative with subsidence rates ranging between $\sim 0.65$ and $\sim 1 \mathrm{~mm} / \mathrm{yr}$ (Fig. 5).

These multiple cycles of uplift and subsidence have already been reported in the coastal areas located near the Phlegrean Fields, in the northern part of the gulf (Fig. 1B; Cinque et al., 1997; Morhange et al., 2006; Aucelli et al., 2018a, 2018b). Along the Naples seafront (central-northern part of the gulf; Fig. 1B), a mean subsidence rate of $1 \mathrm{~mm} /$ yr was estimated by Cinque et al. (2011). This dominant subsiding trend was, however, not linear in space or time. Cinque et al. (2011), and subsequently Romano et al. (2013), argued that minor episodes of uplift or accelerated subsidence related to the volcano-tectonic phenomena of the Phlegrean Fields district are superimposed on the general subsidence rates. Our data support the hypothesis of a period of positive land uplift, which triggered a phase of RSL stabilization between
$\mathrm{AD} \sim 0$ and $\sim 450$, which interrupts the general trend of RSL rise exceeding $2 \mathrm{~mm} / \mathrm{yr}$ in the pre-Augustan period. This period of land uplift also counterbalanced the GIA-driven RSL rise predicted in this time span (Fig. 4). However, no further evidence for RSL stabilization between the first and fifth centuries AD has been reported in the Gulf of Naples. By contrast, the increase in rates of sea-level rise between the late Roman to medieval periods is consistent with a major phase of negative bradyseism (i.e., gradual subsidence) in the Phlegrean Fields (Fig. 1B; Cinque et al., 1997; Morhange et al., 2006; Di Vito et al., 2016), which triggered increased subsidence in the area of Chiaia (Fig. 1C) between the fifth and sixth centuries AD (Romano et al., 2013). Our data seem to indicate that this increase in subsidence also affected the Piazza Municipio area.

These results further confirm the spatial complexity of RSL histories inside the Gulf of Naples, where variability in landlevel changes associated with volcano-tectonics played a dominant role in controlling the RSL evolution during the last four millennia. The causes of the Roman RSL deceleration are unclear. Positive land-level changes were most likely driven by a period of positive bradyseism (i.e., gradual ground movement caused by the filling of the underground caldera) and/or by uplifting trends of the MSFZ footwall, which offset the general subsidence trend of the Gulf of Naples.

\section{Impacts of RSL changes on the evolution of the harbour water column}

The RSL stability observed between the first and the fifth centuries AD had significant implications for the use of the harbour during the Roman period. Silting problems inside the basin, probably related to increased sedimentation, are documented from the Hellenistic period until the second century AD (Di Donato et al., 2018), as testified by widespread evidence of dredging (Fig. 2A).

Figure 6 shows the reconstruction of the water column evolution in the basin according to both the RSL (Fig. 5) and the seafloor position (Fig. 4) during different periods. As stated previously, the maximum draft of the largest vessel found in the Augustan harbour of Naples was $\sim 1.5 \mathrm{~m}$ (Boetto and Poveda, 2018; Fig. 6). Our sea-level record, therefore, confirms that after the construction of the harbour structures (quay and pier) in the Augustan period, the harbour functioned for about two centuries (Giampaola et al., 2006), as testified by the five shipwrecks dated between the end of the first century and the beginning of the third century AD found in the harbour (Fig. 2B; Boetto, 2009; Boetto and Poveda, 2018). By the end of the second century AD, circulation in the harbour started to become more difficult (Fig. 6) probably leading to the decline of port activities recorded in the third to fourth centuries AD (Giampaola et al., 2006). This was also synchronous with a phase of abandonment highlighted by the decrease of horticultural activities around the harbour and the development of wild vegetation (Russo 


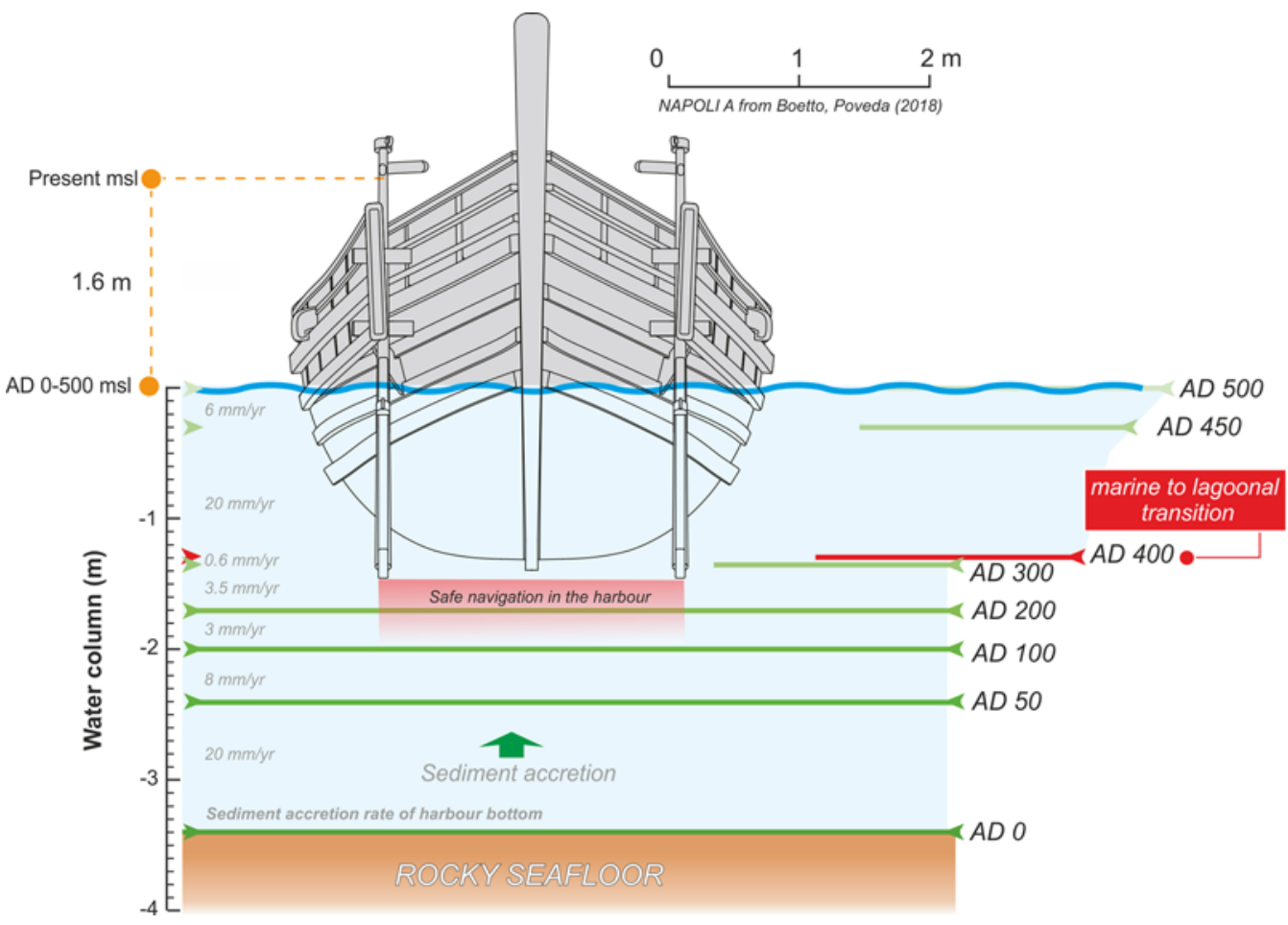

Figure 6. (colour online) Sedimentation rates and evolution of the water column in the harbour basin. The progressive decrease in harbour draft depths is also denoted. Typical draft of the boat found in the harbour is based on Boetto and Poveda (2018). msl, mean sea level.

Ermolli et al., 2014). The sea-level stabilization in the first five centuries $\mathrm{AD}$ seems to have had minimal impacts on the harbour sedimentation. In fact, we observed great variability in the silting rates of the harbour despite the negligible RSL variation during the whole period. This variability is largely controlled by other factors such as deposition of human waste during the harbour apex (Di Donato et al., 2018) and the important sedimentary input linked to the AD 79 eruption and its subsequent reworking. Minimal traces of dredging activity following the eruption were found in front of the quay (Di Donato et al., 2018). However, these sporadic dredging scars cannot account for the sudden decrease in the rates of RSL rise observed from the end of the first century $\mathrm{AD}$, which are probably of natural origin. No evidence of dredging activity was found after this period, further corroborating the progressive decline of harbour activities after the second century AD. Harbour sedimentation rates reincreased significantly only after the transition from a marine infratidal to a lagoonal environment.

\section{CONCLUSIONS}

A multiproxy geoarchaeological investigation allowed us to reconstruct the millennial sea-level evolution in the ancient harbour of Naples, one of the most important Mediterranean cities. In this area, previous geoarchaeological investigations mainly focused on the RSL histories of the Roman to medieval period. Here, we were able to robustly constrain the RSL evolution since the Hellenistic period (end of the third century to second century BC). Since this time, RSL rose with average rates of $\sim 2 \mathrm{~mm} / \mathrm{yr}$ showing a nonmonotonic pattern mostly controlled by the area's complex volcano-tectonic setting. Increased negative land-level changes triggered a rapid RSL rise ( $\sim 2.5$ to $\sim 2.0 \mathrm{~mm} / \mathrm{yr})$ in the first two centuries $\mathrm{BC}$ and in the post-Antiquity period (i.e., since the fifth century AD). This general trend of negative land-level changes was interrupted for five centuries (AD $50 \pm 50$ to $425 \pm 25$ ) when a significant deceleration of the RSL rising rates $(\sim 0.2 \mathrm{~mm} / \mathrm{yr})$ was observed. The causes of this stabilization of the RSL position are most likely related to a positive bradyseism period in the Phlegrean Fields area, even if future investigations are required to better constrain the role of the MSFZ in controlling the sea-level evolution of this densely populated area of the Mediterranean coastline.

Our results further confirm the extremely complex pattern of land-level changes in the Gulf of Naples where detailed spatiotemporal investigations into the variability of ground motion rates associated with volcano-tectonics represent a key tool to better quantify the current coastal hazard.

\section{Acknowledgements}

This article is dedicated to the memory of our friend and colleague Paola Romano who significantly investigated the coastal evolution of Naples in recent years. MV is funded by the Rita Levi Montalcini programme of the Italian Ministry of University and Research (MIUR). CM and MV thank the Labex OT-Med (ANR11-LABX-0061) and the A*MIDEX project (ANR-11-IDEX0001-02). Our study is a contribution to the MOPP-Medflood (INQUA CMP 1603P) and HOLSEA (INQUA CMP 1601P) projects. We also extend our gratitude to the PALSEA 2 (PAGES/ 
INQUA/WUN working group) and IGCP Project 639 communities for fruitful discussions during the workshops. We warmly thank Carlo Nike Bianchi and Carla Morri (DISTAV, University of Genova, Italy) who helped us with the identification of the fossil benthic species. Finally, we thank two anonymous reviewers and the associate editor Barbara Mauz who greatly improved the early version of the manuscript.

\section{REFERENCES}

Aiello, G., Budillon, V., Cristofalo, G., d'Argenio, B., De Alteriis, G., De Lauro, M., Ferraro, L., et al., 2001. Marine geology and morphobathymetry in the Bay of Naples (south-eastern Tyrrhenian sea, Italy). In: Faranda, F.M., Guglielmo, L., Spezi, G. (Eds.), Mediterranean Ecosystems. Springer, Milan, Italy, pp. 1-8.

Aiello, G., Marsella, E., 2015. Interactions between Late Quaternary volcanic and sedimentary processes in the Naples Bay, southern Tyrrhenian sea. Italian Journal of Geosciences 134, 367-382.

Anzidei, M., Lambeck, K., Antonioli, F., Furlani, S., Mastronuzzi, G., Serpelloni, E., Vannucci, G., 2014. Coastal structure, sea-level changes and vertical motion of the land in the Mediterranean. Geological Society, London, Special Publications 388, 453-479.

Aucelli, P.P., Brancaccio, L. and Cinque, A., 2017a. Vesuvius and Campi Flegrei: volcanic history, landforms and impact on settlements. In: Soldati, M., Marchetti, M. (Eds.), Landscapes and Landforms of Italy. Springer, Cham, Switzerland, pp. 389-398.

Aucelli, P., Cinque, A., Giordano, F., Mattei, G., 2016. A geoarchaeological survey of the marine extension of the Roman archaeological site Villa del Pezzolo, Vico Equense, on the Sorrento Peninsula, Italy. Geoarchaeology 31, 244-252.

Aucelli, P.P., Cinque, A., Mattei, G., Pappone, G., 2017b. Late Holocene landscape evolution of the Gulf of Naples (Italy) inferred from geoarchaeological data. Journal of Maps 13, 300-310.

Aucelli, P., Cinque, A., Mattei, G., Pappone, G., Rizzo, A., 2019. Studying relative sea level change and correlative adaptation of coastal structures on submerged Roman time ruins nearby Naples (southern Italy). Quaternary International 501B, 328-348.

Aucelli, P., Cinque, A., Mattei, G., Pappone, G., Stefanile, M., 2018a. Coastal landscape evolution of Naples (Southern Italy) since the Roman period from archaeological and geomorphological data at Palazzo degli Spiriti site. Quaternary International 483, 23-38.

Aucelli, P.P., Cinque, A., Mattei, G., Pappone, G., Stefanile, M., 2018b. First results on the coastal changes related to local sea level variations along the Puteoli sector (Campi Flegrei, Italy) during the historical times. Alpine and Mediterranean Quaternary 31, 13-16.

Auriemma, R., Solinas, E., 2009. Archaeological remains as sea level change markers: a review. Quaternary International 206, 134-146.

Barlow, N.L., Shennan, I., Long, A.J., Gehrels, W.R., Saher, M.H., Woodroffe, S.A., Hillier, C., 2013. Salt marshes as late Holocene tide gauges. Global and Planetary Change 106, 90-110.

Benjamin, J., Rovere, A., Fontana, A., Furlani, S., Vacchi, M., Inglis, R.H., Galili, E., et al., 2017. Late Quaternary sea-level changes and early human societies in the central and eastern Mediterranean Basin: an interdisciplinary review. Quaternary International 449, 29-57.
Bini, M., Fabiani, F., Pappalardo, M., Schuldenrein, J., 2018. Urban geoarchaeology in the Mediterranean basin. Geoarchaeology 33, 3-12.

Boetto, G., 2009. New archaeological evidence of the Horeia-type vessels: the Roman Napoli C shipwreck from Naples (Italy) and the boats of Toulon (France) compared. In: Bockius, R. (Ed.), Proceedings of the 11th International Symposium of Boat and Ship Archaeology. Verlag des römisch-germanischen Zentralmuseums, Mainz, Germany, pp. 289-296.

Boetto, G., Carsana, V., Giampaola, D., 2010. I relitti di Napoli e il loro contesto portuale. Archeologia, storia, etnologia navale: atti del I convegno nazionale, Cesenatico, Museo della Marineria, 4-5 aprile 2008. Edipuglia, Bari, Italy, pp. 115-22.

Boetto, G., Poveda, P., 2018. Napoli A, un voilier abandonné dans le port de Neapolis à la fin du Ier siècle : architecture, fonction, restitution et espace de navigation. In: Boetto, G., Rieth, E. (Eds). De re navali: Pérégrination nautiques entre Méditerranée et océan Indien. Mélanges en l'honneur de Patrice Pomey (Archaeonautica, 20). CNRS éditions, Paris, pp. 19-56.

Brandon, C.J., Hohlfelder, R.L., Jackson, M.D., Oleson, J.P., 2014. Building for Eternity: The History and Technology of Roman Concrete Engineering in the Sea. Oxbow Books, Oxford, UK.

Bruno, P.P.G., Rapolla, A., Di Fiore, V., 2003. Structural setting of the Bay of Naples (Italy) seismic reflection data: implications for Campanian volcanism. Tectonophysics 372, 193-213.

Butzer, K.W., 2008. Challenges for a cross-disciplinary geoarchaeology: the intersection between environmental history and geomorphology. Geomorphology 101, 402-411.

Carsana, V., Febbraro, S., Giampaola, D., Guastaferro, C., Irollo, G., Ruello, M.R., 2009. Evoluzione del paesaggio costiero tra Parthenopee Neapolis. Méditerranée: Revue géographique des pays méditerranéens/Journal of Mediterranean Geography 112, 14-22.

Church, J.A., White, N.J., Aarup, T., Wilson, W.S., Woodworth, P.L., Domingues, C.M., Hunter, J.R., Lambeck, K., 2008. Understanding global sea levels: past, present and future. Sustainability Science 3, 9-22.

Cinquantaquattro, T.E., 2015. L'attività archeologica della Soprintendenza Speciale di Napoli e Pompei. In: La Magna Grecia da Pirro ad Annibale, Atti del LII Convegno di Studi sulla Magna Grecia, Taranto 27-30 settembre 2012. Istituto per la storia e l'archeologia della Magna Grecia, Taranto, Italy, pp. 865-908.

Cinque, A., Aucelli, P.P.C., Brancaccio, L., Mele, R., Milia, A., Robustelli, G., Romano, P., et al., 1997. Volcanism, tectonics and recent geomorphological change in the Bay of Napoli. Supplementi Geografia Fisica Dinamica Quaternaria 3, 123-141.

Cinque, A., Irollo, G., Romano, P., Ruello, M.R., Amato, L., Giampaola, D., 2011. Ground movements and sea level changes in urban areas: 5000 years of geological and archaeological record from Naples (southern Italy). Quaternary International 232, 45-55.

D’Agostino, B., Giampaola, D., 2005. Osservazioni storiche e archeologiche sulla fondazione di Neapolis. Noctes Campanae: studi di storia antica e archeologia dell'Italia pre-romana e romana in memoria di Martin W. Frederiksen. Luciano, Naples, Italy, pp. 63-72.

Deino, A.L., Orsi, G., de Vita, S., Piochi, M., 2004. The age of the Neapolitan Yellow Tuff caldera-forming eruption (Campi Flegrei caldera-Italy) assessed by $40 \mathrm{Ar} / 39 \mathrm{Ar}$ dating method. Journal of Volcanology and Geothermal Research 133, 157-170.

Di Donato, V., Ruello, M.R., Liuzza, V., Carsana, V., Giampaola, D., Di Vito, M.A., Morhange, C., Cinque, A., 
Russo Ermolli, E., 2018. Development and decline of the ancient harbor of Neapolis. Geoarchaeology 33, 542-557.

Di Vito, M.A., Acocella, V., Aiello, G., Barra, D., Battaglia, M., Carandente, A., Del Gaudio, C., et al., 2016. Magma transfer at Campi Flegrei caldera (Italy) before the 1538 AD eruption. Scientific Reports 6, 32245.

Di Vito, M.A., Isaia, R., Orsi, G., Southon, J.D., De Vita, S., d'Antonio, M., Pappalardo, L., Piochi, M., 1999. Volcanism and deformation since 12,000 years at the Campi Flegrei caldera (Italy). Journal of Volcanology and Geothermal Research 91, 221-246.

Di Vito, M.A., Talamo, P., de Vita, S., Rucco, I., Zanchetta, G., Cesarano, M., 2019. Dynamics and effects of the Vesuvius Pomici di Avellino Plinian eruption and related phenomena on the Bronze Age landscape of Campania region (southern Italy). Quaternary International 499B, 231-244.

Felici, E., 1998. La ricerca sui porti romani in cementizio: metodi e obiettivi. In: Volpe, G. (Ed.), Archeologia subacquea - come opera l'archeologo sott'acqua. Storie dalle acque. VIII Ciclo di lezioni sulla Ricerca applicata in Archeologia (Certosa di Pontignano 1996). Edizioni all'Insegna del Giglio, Florence, Italy, pp. 275-340.

Ferranti, L., Antonioli, F., Anzidei, M., Monaco, C., Stocchi, P., 2010. The timescale and spatial extent of vertical tectonic motions in Italy: insights from relative sea-level changes studies. Journal of the Virtual Explorer 36, 30.

Fontana, A., Vinci, G., Tasca, G., Mozzi, P., Vacchi, M., Bivi, G., Salvador, S., et al., 2017. Lagoonal settlements and relative sea level during Bronze Age in northern Adriatic: geoarchaeological evidence and paleogeographic constraints. Quaternary International 439, 17-36.

Galili, E., Weinstein-Evron, M., Ronen, A., 1988. Holocene sealevel changes based on submerged archaeological sites off the northern Carmel coast in Israel. Quaternary Research 29, 36-42.

Giampaola, D., 2017. Parthenope, Neapolis e il suo porto. In: Osanna, M., Rescigno, C. (Eds.), Pompei e $i$ Greci. Electa, Milan, Italy, pp. 207-213.

Giampaola, D., 2018. Da Palepoli a Neapolis: lo strutturarsi del fronte costiero. In: LVIII Convegno Internazionale di Studi sulla Magna Grecia: La Magna Grecia nel Mediterraneo in età arcaica e classica. Forme, mobilità, interazioni, Taranto, 27-30 settembre 2018. Istituto per la storia e l'archeologia della Magna Grecia, Taranto, Italy,

Giampaola, D., Boenzi, G., 2013. Interazione tra attività vulcanica e vita dell'uomo: evidenze archeologiche nell'area urbana di Napoli. In: Di Vito, M.A., de Vita, S. (Eds.), Compendio delle lezioni Scuola estiva AIQUA 2013. Miscellanea INGV No. 18. INGV, Naples, Italy, pp. 38-44

Giampaola, D., Carsana, V., 2005. Neapolis. Le nuove scoperte: la città, il porto e le macchine. In: Lo Sardo, E. (Ed.), Eureka! il genio degli antichi, catalogo della mostra, Museo Archeologico Nazionale di Napoli, 11 luglio 2005-9 gennaio 2006. Electa, Naples, Italy, pp. 116-122.

Giampaola, D., Carsana, V., Boetto, G., Crema, F., Florio, C., Panza, D., Pizzo, B., et al., 2006. La scoperta del porto di "Neapolis": dalla ricostruzione topografica allo scavo e al recupero dei relitti. Archaeologia Maritima Mediterranea: An International Journal on Underwater Archaeology 2, 47-91.

Goffredo, S., Mezzomonaco, L., Zaccanti, F., 2004, Genetic differentiation among populations of the Mediterranean hermaphroditic brooding coral Balanophyllia europaea (Scleractinia: Dendrophylliidae). Marine Biology 6, 1075-1083.
Kemp, A.C., Horton, B.P., Donnelly, J.P., Mann, M.E., Vermeer, M., Rahmstorf, S., 2011. Climate related sea-level variations over the past two millennia. Proceedings of the National Academy of Sciences of the United States of America 108, 11017-11022.

Khan, N.S., Ashe, E., Shaw, T.A., Vacchi, M., Walker, J., Peltier, W.R., Kopp, R.E., Horton, B.P., 2015. Holocene relative sea-level changes from near-, intermediate-, and far-field locations. Current Climate Change Reports 1, 247-262.

Kolaiti, E., Papadopoulos, G.A., Morhange, C., Vacchi, M., Triantafyllou, I., Mourtzas, N. D., 2017. Palaeoenvironmental evolution of the ancient harbor of Lechaion (Corinth Gulf, Greece): were changes driven by human impacts and gradual coastal processes or catastrophic tsunamis? Marine Geology 392, 105-121.

Laborel, J., Laborel-Deguen, F., 1994. Biological indicators of relative sea-level variations and of co-seismic displacements in the Mediterranean region. Journal of Coastal Research 10, 395-415.

Lambeck, K., Antonioli, F., Anzidei, M., Ferranti, L., Leoni, G., Scicchitano, G., Silenzi, S., 2011. Sea level change along the Italian coast during the Holocene and projections for the future. Quaternary International 232, 250-257.

Lambeck, K., Anzidei, M., Antonioli, F., Benini, A., Esposito, A. 2004. Sea level in Roman time in the central Mediterranean and implications for recent change. Earth and Planetary Science Letters 224, 563-575.

Liuzza, V., 2014. Ricostruzione paleogeografica e paleoambientale della città di Napoli: Un'indagine geoarcheologica. PhD dissertation, University of Naples Federico II, Naples, Italy.

Marriner, N., Kaniewski, D., Morhange, C., Flaux, F., Giaime, M., Vacchi, M., Goff, J., 2017. Tsunamis in the geological record: making waves with a cautionary tale from the Mediterranean. Science Advances, 3, e1700485.

Mattei, G., Troisi, S., Aucelli, P.P.C., Pappone, G., Peluso, F., Stefanile, M., 2018. Sensing the submerged landscape of Nisida Roman Harbour in the Gulf of Naples from integrated measurements on a USV. Water 10, 1686.

Milia, A., Torrente, M.M., 2003. Late-Quaternary volcanism and transtensional tectonics in the Bay of Naples, Campanian continental margin, Italy. Mineralogy and Petrology 79, 49-65.

Milia, A., Torrente, M.M., Giordano, F., Mirabile, L., 2006. Rapid changes of the accommodation space in the Late Quaternary succession of Naples Bay, Italy: the influence of volcanism and tectonics. Developments in Volcanology 9, 53-68.

Milne, G.A., Long, A.J., Bassett, S.E., 2005. Modeling Holocene relative sea-level observations from the Caribbean and South America. Quaternary Science Reviews 24, 1183-1202.

Morhange, C., Marriner, N., 2010. Mind the (stratigraphic) gap: Roman dredging in ancient Mediterranean harbours. Bollettino di Archeologia on line, Volume Speciale, 23-32.

Morhange, C., Marriner, N., 2015. Archeological and biological relative sea-level indicators. In: Shennan, I., Long, A.J., Horton, B.P. (Eds.), Handbook of Sea-Level Research. John Wiley and Sons, Chichester, West Sussex, UK, pp.146-156.

Morhange, C., Laborel, J., Hesnard, A., 2001. Changes of relative sea level during the past 5000 years in the ancient harbor of Marseilles, southern France. Palaeogeography, Palaeoclimatology, Palaeoecology 166, 319-329.

Morhange, C., Marriner, N., Excoffon, P., Bonnet, S., Flaux, C., Zibrowius, H., Goiran, J.P., Amouri, M.E., 2013. Relative sea-level changes during Roman times in the northwest 
Mediterranean: the 1st century A.D. fish tank of Forum Julii, Fréjus, France. Geoarchaeology 28, 363-372.

Morhange, C., Marriner, N., Laborel, J., Todesco, M., Oberlin, C., 2006. Rapid sea-level movements and noneruptive crustal deformations in the Phlegrean Fields caldera, Italy. Geology 34, 93-96.

Oleson, J.P., 1988. The technology of Roman harbours. International Journal of Nautical Archaeology 17, 147-157.

Orsi, G., Di Vito, M.A., Isaia, R., 2004. Volcanic hazard assessment at the restless Campi Flegrei caldera. Bulletin of Volcanology 66, 514-530.

Peltier, W.R., 2004. Global glacial isostasy and the surface of the ice-age Earth: the ICE-5 G (VM2) model and GRACE. Annual Review of Earth and Planetary Science, 32, 111-149.

Pirazzoli, P.A., 1997. Sea-level changes: the last 20000 years. Oceanographic Literature Review 8, 785.

Reimer, P.J., Bard, E., Bayliss, A., Beck, J.W., Blackwell, P.G., Ramsey, C.B., Buck, C.E., et al., 2013. IntCal13 and Marine13 radiocarbon age calibration curves $0-50,000$ years cal BP. Radiocarbon 55, 1869-1887.

Romano, P., Di Vito, M.A., Giampaola, D., Cinque, A., Bartoli, C., Boenzi, G., Detta, F., et al., 2013. Intersection of exogenous, endogenous and anthropogenic factors in the Holocene landscape: a study of the Naples coastline during the last 6000 years. Quaternary International 303, 107-119.

Rovere, A., Antonioli, F., Bianchi, C.N., 2015. Fixed biological indicators. In: Shennan, I., Long, A.J., Horton, B.P. (Eds.), Handbook of Sea-Level Research. John Wiley and Sons, Chichester, West Sussex, UK, pp. 268-280.

Roy, K., Peltier, W.R., 2018. Relative sea level in the western Mediterranean basin: a regional test of the ICE-7G_NA (VM7) model and a constraint on late Holocene Antarctic deglaciation. Quaternary Science Reviews 183, 76-87.

Russo Ermolli, E., Romano, P., Ruello, M.R., Barone Lumaga, M.R., 2014. The natural and cultural landscape of Naples (southern Italy) during the Graeco-Roman and Late Antique periods. Journal of Archaeological Science 42, 399-411.

Sabatier, P., Dezileau, L., Colin, C., Briqueu, L., Bouchette, F., Martinez, P., Siani, G., Raynal, O., Von Grafenstein, U., 2012. 7000 years of paleostorm activity in the NW Mediterranean Sea in response to Holocene climate events. Quaternary Research $77,1-11$.

Santangelo, N., Romano, P., Ascione, A., Russo Ermolli, E., 2017. Quaternary evolution of the Southern Apennines coastal plains: a review. Geologica Carpathica 68, 43-56.

Satta, A., Puddu, M., Venturini, S., Giupponi, C., 2017. Assessment of coastal risks to climate change related impacts at the regional scale: the case of the Mediterranean region. International Journal of Disaster Risk Reduction 24, 284-296.

Seeliger, M., Pint, A., Frenzel, P., Feuser, S., Pirson, F., Riedesel, S., Brückner, H., 2017. Foraminifera as markers of Holocene sealevel fluctuations and water depths of ancient harbours-a case study from the Bay of Elaia (W Turkey). Palaeogeography, Palaeoclimatology, Palaeoecology 482, 17-29.

Sgarrella, F., Moncharmont-Zei, M., 1993. Benthic foraminifera of the Gulf of Naples (Italy): systematics and autoecology. Bolletino della Societa Paleontologica Italiana 32, 145-264.

Shennan, I., Long, A.J., Horton, B.P. (Eds.), 2015. Handbook of Sea-Level Research. John Wiley and Sons, Chichester, West Sussex, UK.

Siani, G., Paterne, M., Arnold, M., Bard, E., Métivier, B., Tisnerat, N., Bassinot, F., 2000. Radiocarbon reservoir ages in the Mediterranean Sea and Black Sea. Radiocarbon 42, 271-280.

Smith, V.C., Isaia, R., Pearce, N.J.G., 2011. Tephrostratigraphy and glass compositions of post-15 kyr Campi Flegrei eruptions: implications for eruption history and chronostratigraphic markers. Quaternary Science Reviews 30, 3638-3660.

Spada, G., \& Stocchi, P. (2007). SELEN: A Fortran 90 program for solving the "sea-level equation". Computers \& Geosciences, 33 (4), 538-562

Stuiver, M., Reimer, P.J., Reimer, R.W., 2019. CALIB 7.1 [World Wide Web program] (accessed 13/01/2019). http://calib.org.

Vacchi, M., De Falco, G., Simeone, S., Montefalcone, M., Morri, C., Ferrari, M., Bianchi, C.N., 2017. Biogeomorphology of the Mediterranean Posidonia oceanica seagrass meadows. Earth Surface Processes and Landforms 42, 42-54.

Vacchi, M., Ghilardi, M., Melis, R.T., Spada, G., Giaime, M., Marriner, N., Lorscheid, T., Morhange, C., Burjachs, F., Rovere, A., 2018. New relative sea-level insights into the isostatic history of the western Mediterranean. Quaternary Science Reviews 201, 396-408.

Vacchi, M., Marriner, N., Morhange, C., Spada, G., Fontana, A., Rovere, A., 2016. Multiproxy assessment of Holocene relative sea-level changes in the western Mediterranean: sea-level variability and improvements in the definition of the isostatic signal. Earth-Science Reviews 155, 172-197.

Vacchi, M., Rovere, A., Chatzipetros, A., Zouros, N., Firpo, M., 2014. An updated database of Holocene relative sea level changes in NE Aegean Sea. Quaternary International 328, 301-310.

van de Plassche, O., 1982. Sea-level change and water-level movements in the Netherlands during the Holocene. Mededelingen Rijks Geologische Dienst 36, 1-93. 